\title{
A Abordagem Temática Caracterizada por Pesquisadores da Área de Ensino de Ciências
}

\section{The Thematic Approach as Seen by Researchers in the Field of Science Education}

\author{
Thiago Flores Magoga $₫$ Brasil \\ Cristiane Muenchen ${ }^{\circledR}$ Brasil
}

Entendida como uma perspectiva curricular que tem por base o trabalho a partir de temas, a Abordagem Temática vem sendo sinalizada pela literatura da área como possibilidade para a problematização de alguns desafios relacionados ao processo educacional. O presente artigo é recorte de uma pesquisa mais ampla e objetiva discutir características das ações de um coletivo de pesquisadores que têm construído e disseminado conhecimento sobre essa perspectiva. $\mathrm{O}$ coletivo de pesquisadores foi delimitado por meio de um processo de revisão bibliográfica, realizado à luz da epistemologia de Fleck, nos principais períodicos da área de ensino de ciências. Dessa forma, após a realização de entrevistas com cinco professores/pesquisadores da área de ensino de ciências, os quais têm como similaridade a formação inicial em Física, perceberam-se características comuns em relação às suas ações via Abordagem Temática. Essas características foram organizadas e apresentadas a partir de três categorias, emergidas do processo da Análise Textual Discursiva. Após a apresentação e discussão de cada uma dessas categorias e de suas respectivas sub-categorias, sinaliza-se a importância que essas possuíram para a identificação dos modos de pensar e agir do coletivo de professores/pesquisadores, possibilitando a compreensão de como a Abordagem Temática vem sendo disseminada dentro da área.

Palavras-chave: Abordagem Temática; Freire; Currículo.

Understood as a curricular perspective based on work made from thematic units, literature has indicated the Thematic Approach as a possibility for problematizing some challenges related to the educational process. This article is part of a broader research and aims to discuss characteristics of the actions of a group of researchers that have built and disseminated knowledge on this approach. We chose the collective of researchers based on a bibliographic review process, carried out in the light of Fleck's epistemology, using the top journals on the field of science education. Thus, after conducting an interview with five professors/researchers from the field of science education, who share a degree in Physics, we perceived common characteristics in relation to their actions about Thematic Approach. These characteristics were organized and presented from three categories, which emerged from the process of Discursive Textual Analysis. After presenting and discussing each of these categories and their respective sub-categories, we 
indicate the importance of these categories for the identification of the ways of thinking and acting of the professors/researchers group, enabling the understanding of how the Thematic Approach has disseminated in the field of Science Education.

Keywords: Thematic Approach; Freire; Curriculum.

\section{Discussões iniciais}

Diferentes autores da área de ensino de ciências, almejando a formação de educandos/sujeitos capazes de entender o contexto à sua volta e de se posicionar de forma participativa e transformadora, têm buscado a construção de um currículo crítico, dinâmico, e que abarque os reais problemas das comunidades escolares brasileiras (Auler, \& Delizoicov, 2006; Centa, 2015; Muenchen, 2010).

Autores como Dalmolin e Roso (2012) e Strieder, Caramello e Gehlen (2010) têm, nesse sentido, sinalizado e defendido construções curriculares baseadas na chamada Abordagem Temática (AT), pois esta - além de estar ganhando relativo destaque dentro da área - apresenta-se como uma proposta que entende o currículo escolar como "identidade" da comunidade escolar. Para os autores supracitados, os currículos são marcados por intencionalidades e, por isso, devem ser construídos de forma participativa, problematizando as demandas sociais e possibilitando a transformação social.

Partindo das premissas apresentadas nos parágrafos acima, o presente artigo propõem-se a abordar como alguns pesquisadores entendem e têm trabalhado com esta perspectiva curricular. Dessa forma, o objetivo deste artigo é discutir os modos de pensar e agir de um coletivo de pesquisadores que trabalha com a AT, a partir de categorias construídas com base em análises derivadas de entrevistas.

Torna-se importante destacar que as discussões deste artigo compõem os resultados de uma pesquisa de mestrado, mais ampla, em que se realiza uma análise curricular e epistemológica sobre a AT, utilizando-se dos conceitos de Fleck (2010). Esta pesquisa mais ampla visa responder ao seguinte problema: "Como se constitui o círculo esotérico de pesquisadores que, na área de Educação em Ciências, desenvolve ações a partir da Abordagem Temática? Quais elementos teóricos e práticos auxiliam na caracterização do Estilo de Pensamento deste coletivo?”.

No presente trabalho serão exploradas - em maior grau - análises relativas à segunda questão do problema acima, isto é, serão caracterizados os modos de pensar (teórico) e agir (prático) daqueles sujeitos. Por sua vez, por se tratarem de análises epistemológicas, mais amplas, tais caracterizações moldam a estrutura de um Estilo de Pensamento (Fleck, 2010), do coletivo de pesquisadores, em relação à AT.

Sendo assim, na sequência, após uma explanação acerca da AT - aborda-se, brevemente, seu histórico de construção e suas principais características -, apresentam-se a metodologia e os resultados. Torna-se importante destacar, novamente, que o conteúdo dessas categorias possibilitou caracterizar o Estilo de Pensamento dos pesquisadores especialistas que produzem conhecimento envolvendo a AT. 


\section{Abordagem Temática: "outro olhar" para o processo educativo}

Tem sido consenso, entre autores da área do ensino de ciências que discutem currículo, o fato de que repensar os objetivos, as ações e a organização da escola significa repensar a própria constituição espaço-tempo dela, o que perpassa a problematização e a reconstrução do currículo escolar (Auler, 2007; Centa, \& Muenchen, 2016; Halmenschlager, 2011).

Ao discutir as questões relacionadas à educação, ou mais especificamente à educação em ciências, Dalmolin e Roso (2012), dentre outros autores, também expõem a necessidade de repensar o currículo escolar e indicam a possibilidade de trabalhar a partir da Abordagem Temática (AT), superando, justamente, o caráter linear, fragmentado e propedêutico. Segundo Delizoicov, Angotti e Pernambuco (2011), tal abordagem "é uma perspectiva curricular cuja lógica de organização é estruturada com base em temas, com os quais são selecionados os conteúdos de ensino das disciplinas. Nessa abordagem, a conceituação científica da programação é subordinada ao tema" (p.189).

Além dos próprios autores (Delizoicov, Angotti e Pernambuco, 2011), Muenchen (2010) defende que a AT supera o que se denomina Abordagem Conceitual - onde a ênfase é apenas no conceito científico, como um fim e em si mesmo -, pois, nela (AT), utiliza-se o conceito científico para a compreensão de algo maior: o próprio tema.

Baseando-se na literatura existente, percebe-se que um dos primeiros trabalhos a discutir alguns dos aspectos da AT é o de Pierson (1997). Neste, a autora debate, como o próprio título sugere, "O Cotidiano e a Busca de Sentido para o Ensino de Física".

Durante o seu trabalho de doutoramento, Pierson (1997) realizou uma pesquisa de revisão bibliográfica nas atas dos Simpósios Nacionais de Ensino de Física (SNEFs), na tentativa de caracterizar como a Física tratava/trabalhava com o "cotidiano". Após a discussão acerca dos aspectos epistemológicos envolvendo o "cotidiano" e de apresentar a própria metodologia utilizada para a revisão bibliográfica, a autora identifica, em seus resultados, duas linhas de pesquisas, denominadas, assim, "Pesquisas em Concepções Espontâneas" e "Abordagens Temáticas".

A então considerada linha de pesquisa "Abordagens Temáticas", segundo Pierson (1997), via o cotidiano como um espaço de organização e seleção do conteúdo a ser desenvolvido, de modo que tal linha apresentava preocupação com a revitalização dos conteúdos. Segundo ela,

Diferentemente de outras abordagens onde a questão do conteúdo de física aparece de forma periférica, nesta abordagem ela aparece como essencial, seja em discussões sobre a sua importância, como defini-los ou como organizá-los. Enfim, o que ensinar não é tomado como um dado a priori, mas como uma escolha consciente onde fatores pedagógicos convivem com fatores epistemológicos e sociais (Pierson, 1997, p. 153).

A pesquisa de Pierson (1997) mostrou que a da origem da AT está muito atrelada ao componente curricular Física. No decorrer de sua tese, a autora explicita que o desenvolvimento inicial dessa perspectiva está relacionada ao grupo "Reelaboração de 
Conteúdo e Formação de Professores" vinculado ao Departamento de Física Experimental do Instituto de Física da Universidade de São Paulo. Ainda segundo descrição de Pierson (1997), o grupo era formado pelos professores Luis Carlos de Menezes, Yassuko Hosoume, João Zanetic, Maria Regina D. Kawamura, em colaboração com os professores Demétrio Delizoicov e José André Angotti, da Universidade Federal de Santa Catarina, assim como a professora Marta Maria Castanho A. Pernambuco da Universidade Federal do Rio Grande do Norte.

Observando alguns dos trabalhos desses professores, como por exemplo em Delizoicov (1983) e Menezes (1980) - anteriores a tese de Pierson -, percebem-se características de como o grupo pensava organizava os seus trabalhos: tendo por base ideais freireanos.

Ao efetuar as leituras dos trabalhos de Menezes e Delizoicov, citados acima, observa-se que existe uma forte relação entre a perspectiva freireana - a qual entende o ser como sujeito, e não objeto; que almeja, portanto, a constante problematização em busca do "ser mais"; que compreende a educação como práxis: caracaterísticas descritas pelos autores (Delizoicov, 1983; Menezes, 1980) - com a linha de pesquisa identificada por Pierson (1997). No decorrer da própria investigação, a autora relaciona a influência de Freire nas construções do grupo "Reelaboração de Conteúdo e Formação de Professores". De acordo com ela,

O pensamento de Paulo Freire tem sido uma referência constante, dando uma direção que, se em alguns momentos é também metodológica, boa parte das vezes mostra-se não apenas enquanto o pensamento de um educador, mas a visão de mundo de um epistemólogo que, mesmo nunca tendo reconhecido-se como tal, não deixa de fornecer elementos sobre os quais pode-se fundamentar uma visão de conhecimento baseada na dialogicidade e problematização, pressupostos indispensáveis para a construção de um conhecimento emancipatório e conscientizador (Pierson, 1997, p. 154).

A apropriação dos elementos freireanos pelos professores idealizadores da AT pode ser identificada, ainda, no trabalho realizado em São Paulo do Potengui (RN), denominado "Ensino de Ciências a Partir dos Problemas da Comunidade" (Pernambuco, 1981) e, mais recentemente, no projeto "Interdisciplinar Via Tema Gerador", em São Paulo, quando o próprio Freire fora secretário municipal de educação (São Paulo, 1990; 1992). Em ambas as experiências, as dicotomias locais foram problematizadas e trabalhadas por meio de reestruturações curriculares via AT, a partir da coordenação de sujeitos que faziam parte do Grupo de Reelaboração de Conteúdo.

Ao trazer o foco para a questão do conteúdo, a AT (linha de pesquisa, como definida por Pierson), passa a problematizar não mais apenas a questão do "como ensinar?" (como se o conteúdo já estivesse definido, a priori, inquestionável), mas também, e principalmente, passam-se a perguntar “o que?" e "por que ensinar?". Segundo Schneider, Centa, Ilha Magoga e Muenchen (2014), esse é um elemento diferenciador quando se trata de currículo e que também está atrelado à definição que, anos mais tarde, com a publicação do livro "Ensino de Ciências: Fundamentos e Métodos" em 2002, 
Delizoicov, Angotti e Pernambuco (2011) deram para a AT: "perspectiva curricular cuja lógica de organização é estruturada com base em temas, com os quais são selecionados os conteúdos de ensino das disciplinas. Nessa abordagem, a conceituação científica da programação é subordinada ao tema" (p. 189).

Ao discutir sobre a relevância da AT no ensino de ciências, Giacomini e Muenchen (2015) apontam alguns objetivos que, para eles, a perspectiva destina-se. Dentre alguns objetivos, destacam-se o fato dela "Produzir uma articulação entre os conteúdos programáticos e os temas abordados; [...] Levar o aluno a pensar de forma articulada e contextualizada com sua realidade e fazer com que ele possa ser ator ativo do processo de ensino/aprendizagem" (Giacomini, \& Muenchen, 2015, p. 342).

Percebe-se, novamente, nos próprios objetivos elencados pelos autores, algumas relações com a perspectiva de Freire, pois este sempre prezou pela não negação dos saberes de experiência feitos e pela importância - da problematização - do contexto local. Por isso, também, a ênfase às palavras geradoras e ao universo vocabular (Freire, 2011c), as quais são oriundas das contradições e problemas do contexto estudado/ problematizado junto com a comunidade (que é vista como "sujeito" ativo no processo).

Atualmente, outras características, também são consideradas essenciais e possibilitam pensar a AT como uma perspectiva curricular. De certa forma, compartilhar dos pressupostos desta implica em ter outro olhar para o diálogo, a problematização, a interdisciplinaridade e, no limite, portanto, para o currículo.

A questão dialógica, em uma AT, deve ser entendida como um processo, de modo que esse diálogo deve fazer parte desde a definição do tema a ser trabalho, perpassando pela escolha dos conteúdos e culminando na própria sala de aula. Expresso em outros termos, compreende todas as etapas da elaboração e implementação do tema. Neste sentido, o diálogo que está se propondo não é um mero blá-blá-blá, mas um diálogo que, respeitando os educandos, auxilie na problematização em torno de um olhar crítico do mundo e de seu contexto:

É retomando e valorizando seletivamente o conhecimento e a forma de pensar do aluno que o estamos ajudando a sentir-se como sujeito de seu mundo, digno de respeito e capaz de atuar nele. Ao dar-lhe oportunidade de olhar esse mesmo mundo e cotidiano à distância, de questioná-lo, criamos nele a necessidade de acesso a um novo conhecimento, o sistematizado (Pernambuco, 2002, p. 25).

Silva (2004) também compartilha a noção de que o diálogo deve constituir-se em torno de problemas reais. Para o autor, durante a ação pedagógica, é necessário considerar e dialogar com os sujeitos pertencentes ao processo educativo e principalmente com os seus saberes, na intenção de propiciar a construção de conhecimento necessário para a intervenção no real.

A partir das ponderações efetuadas, percebe-se que dialogar e problematizar estão intimamente interligados entre si e associados à perspectiva da AT. Tais processos são importantes não só porque auxiliam na constituição de uma perspectiva críticotransformadora, mas também porque resgatam a vocação ontológica do ser sujeito e não 
objeto (Freire, 1987).

Além destas duas características, outro fator importante refere-se ao papel das disciplinas escolares na construção curricular e de suas interações, remetendo ao trabalho interdisciplinar. $\mathrm{Na}$ perspectiva da AT, porém, entende-se, a partir da literatura da área, a interdisciplinaridade como um processo (Centa, 2015), assim como - igualmente importante e dependente - (d) o diálogo e (d) a problematização. Além de Centa (2015), Muenchen (2006) também expõe a interdisciplinaridade como um processo de construção coletiva, em que "numa perspectiva de mudança curricular, obriga o educador repensar e mudar suas posturas" (p. 72), o que pode acarretar dificuldades, pois "é um processo lento e demorado, onde as especificidades de cada área não "desaparecem”, continuam sendo respeitadas" (p. 72).

No âmbito da AT, como sinalizado por Muenchen (2006), entende-se que a interdisciplinaridade não esquece ou limita o trabalho de cada disciplina individualmente. Isto é, a interdisciplinaridade existe na medida em que existe a disciplinaridade. $\mathrm{O}$ que ocorre, no entanto, é que tais disciplinas dialogam em torno do objeto de estudo (tema), problematizando-o, cada uma a sua especificidade (por isso, a importância do diálogo e da problematização). Ademais, entende-se que o tema desenvolvido pela AT não é algo estático, muito menos atemporal, ou - permita-se o termo - "aproblemático". Por abarcar, portanto, diferentes contextos e problemas, o tratamento dado a tal tema requer, indubitavelmente, o "olhar" das diferentes disciplinas. Apesar de, em muitos casos, ser desenvolvido por apenas uma disciplina, um tema, na perspectiva da AT, não é disciplinar.

Entende-se, com isso, que a perspectiva da AT requer, indubitavelmente, uma discussão curricular ampla, em que aspectos pedagógicos e metodológicos articulamse aos curriculares e, portanto, aos políticos (Schneider, et al., 2014). Dessa maneira, o currículo escolar não é entendido apenas como uma lista de conceitos, estático, mas passa a ser construído por diferentes sujeitos, sendo reflexo destes e de suas comunidades (Halmenschlager, 2011).

As asserções acima também são compartilhadas por Centa, Schneider, Magoga e Muenchen (2015), os quais acrescentam que a AT preza por um currículo interdisciplinar, dialógico e problematizador, que contribua no desenvolvimento de questões sociais, éticas, políticas e econômicas, trabalhando, assim, de maneira a contribuir com um ensino de ciências que vincula os conceitos científicos aos temas, procurando trazer a realidade dos educandos para a sala de aula.

Apesar de originalmente, como apontado por Pierson (1997) os pressupostos de Freire estarem muito relacionados à AT, atualmente, de acordo com Magoga, Schneider, Centa e Muenchen (2015), diferentes podem ser as modalidades dessa abordagem. Para os autores:

[...] apesar da relação existente entre Freire e AT, atualmente, entende-se que diferentes podem ser as propostas baseadas na perspectiva aqui apresentada. Pode-se citar como exemplos a Abordagem Temática Freireana (ATF) (Delizoicov, 1991; Silva, 2004; 
Torres, 2010), a Abordagem Temática com repercussões educacionais do movimento Ciência-Tecnologia-Sociedade (CTS) (Santos, \& Mortimer, 2001; Pinheiro, Silveira, \& Bazzo, 2007), a Abordagem Temática Freire-CTS (Auler, Dalmolin, \& Fenalti, 2009; Muenchen, \& Auler, 2007) e alguns autores apontam também a Situação de Estudo (Halmenschlager, 2010). (Magoga, et al., 2015, p. 3).

Neste momento é necessário apontar que as modalidades descritas na citação anterior encontram similiaridades, entre si e com a AT, por se tratarem de abordagens com temas. Nos resultados deste artigo são tecidos comentários sobre a possibilidade destas modalidades serem consideradas Abordagens Temáticas ${ }^{1}$. Além disso, reitera-se a característica principal da AT, associada à questão curricular: lógica em que os conceitos são subordinados aos temas; e que, muitas vezes, as especificações "Freireana", "CTS", estão associadas às formas de definições dos temas.

Na sequência, será apresentado o processo metodológico que guiou este trabalho para, posteriormente, ser realizada a discussão dos resultados com base nas ações desenvolvidas pelos pesquisadores entrevistados.

\section{Apresentação metodológica}

Como comentado anteriormente, o foco deste trabalho é discutir características de como alguns pesquisadores da área de ensino de ciências entendem e trabalham com a AT. A escolha pelos pesquisadores ocorreu pois se identificou, através de um processo de revisão bibliográfica realizado por Magoga (2017), que estes fazem parte do círculo esotérico $^{2}$ de sujeitos que constroem conhecimento sobre essa perspectiva curricular, e são portadores de um Estilo de Pensamento ${ }^{3}$ (Fleck, 2010).

Destaca-se, de antemão, que os sujeitos do círculo esotérico são considerados vanguardistas em determinado conhecimento, ou seja, pensam, estruturam e disseminam ideias e ações. Para Fleck (2010), o círculo esotérico de sujeitos, além de ser formado pelos “experts" em relação a um "objeto de conhecimento" (assunto/tema/problema, ou, no caso, a AT), é responsável pela construção de conhecimento sobre este objeto. Por isso, para o autor, "a partir do saber especializado (esotérico), surge o saber popular" (Fleck, 2010, p. 166).

Por isso mesmo, como descrito em Magoga (2017), o processo de revisão bibliográfica foi realizado em periódicos de qualis A, considerados referências na área,

1 Com isso, está-se a considerar - até mesmo por questões de raízes curriculares e epistemológicas - a distinção entre Abordagem Temática e abordagem por temas. Na visão dos autores deste trabalho - embasada nos resultados descritos, na sequência - pode-se considerar a AT como uma das possíveis formas de abordagens por temas.

2 A terminologia "Círculo Esotérico" deriva da epistemologia Fleckiana e não será aprodundada neste trabalho. Em síntese, o "círculo esotérico" é composto pelos principais sujeitos/pesquisadores que, vanguardistas, constroem e disseminam conhecimentos sobre determinado objeto de conhecimento. Ademais, a característica fundamental desse círculo é que todos os sujeitos compartilham de um mesmo "Estilo de Pensamento".

3 Também categoria Fleckiana, o "Estilo de Pensamento", em termos simples, é constituído pelo modo de se pensar e agir em relação a um objeto de estudo, reunindo, portanto, as concepções, os pensamentos e as ações de determinados sujeitos. A partir das palavras de Fleck (2010), podemos "definir o estilo de pensamento como percepção direcionada em conjunção com o processamento correspondente no plano mental e objetivo" (p. 149). 
pois a tendência é que os especialistas do coletivo de pensamento identificados (os autores referência na área quando se trata de AT), produzam, divulguem, (re)construam e disseminem conhecimentos, promovendo a troca de experiências e o debate entre pares, de modo legítico e coletivo, nesses periódicos.

Sendo assim, inicialmente realizou-se a busca por trabalhos que tratassem da AT nos seguintes periódicos: Ciência \& Educação, Ensaio, Investigações em Ensino de Ciências e na Revista Brasileira de Pesquisa em Educação em Ciências. Para a seleção dos trabalhos que compuseram o corpus de análise, adotou-se uma série de etapas, dentre as quais: escolha do termo/critério de seleção; busca por trabalhos que continham o termo; leituras e releituras dos trabalhos.

Após esta etapa de seleção dos trabalhos, verificou-se a recorrência de autores e optou-se por entrevistar cinco dos sujeitos que mais publicaram trabalhos, tratando da AT. Esses sujeitos/pesquisadores serão identificados pelo códico P1, P2, P3, P4 e P5. A ideia, portanto, é que o coletivo de professores/pesquisadores entrevistado compõemse pelos principais sujeitos que desenvolvem pensamentos e ações com a AT, dentro da área do ensino de ciências.

Dessa forma por meio do programa Skype e presencialmente, realizaram-se entrevistas semiestruturadas com estes cinco professores/pesquisadores. Tais entrevistas foram composta por oito questões ${ }^{4}$.

Destaca-se que na entrevista semiestruturada, segundo Zanella (2009), o pesquisador, ao realizar o diálogo com o entrevistado, dispõe de um "roteiro-guia", ou seja, de questões previamente estabelecidas e estruturadas de acordo com o seu interesse. O rumo que a entrevista tomará não necessariamente segue a ordem cronológica das questões, de modo que, e este é o principal destaque, o perguntante/entrevistador pode acrescentar novos questionamentos ao longo do diálogo. Durante a realização das entrevistas, portanto, o ordenamento das questões não foi linear.

Torna-se importante destacar que os resultados derivados das entrevistas foram analisados segundo pressupostos da Análise Textual Discursiva (ATD) (Moraes, \& Galiazzi, 2007). A escolha por tal método justifica-se pelo fato dela constituir uma importante forma de análise para pesquisas de cunho qualitativo (como é o caso) em que, de acordo com Moraes (2003), tem-se como prerrogativa o estudo criterioso da compreensão dos fenômenos investigados. Também, neste sentido, Moraes e Galiazzi (2007) expressam que a ATD "corresponde a uma metodologia de análise de dados e informações de natureza qualitativa com a finalidade de produzir novas compreensões sobre os fenômenos e discursos" (p. 7).

4 As questões que sulearam a entrevistam foram: 1) Você saberia informar como surgiu a perspectiva da Abordagem Temática?; 2) Como você teve contato ou conheceu a perspectiva da Abordagem Temática? Alguma obra ou pessoa foi central neste contato?; 3) Para você, qual(is) a(s) principais características/objetivos da Abordagem Temática?; 4) Para você, quais são as perspectivas de "Abordagem Temática" mais recorrentes? O que às diferencia de uma abordagem por temas?; 5) Com qual perspectiva de AT você se identifica/trabalha? Por que?; 6) Como você trabalha com esta perspectiva de AT? Com mais reflexões teóricas ou ações práticas? O foco é para qual nível de ensino?; 7) Quais as principais potencialidades com o trabalho via AT? 8) E quais as principais dificuldades para o trabalho via AT? Como superar estas? 
Após a realização das entrevistas, estas foram transcritas e serviram de corpus de análise. Das análises dessas transcrições, realizou-se a etapa denominada de unitarização caracterizada pela "desconstrução" dos materiais, destacando seus elementos a partir das "unidades de significados". Após a seleção dessas "unidades de significados", durante o processo de categorização, agruparam-se as unidades próximas ou semelhantes e, por fim, com base nas categorias construídas, desenvolveu-se a última etapa da ATD, denominada de comunicação, na qual se descreveu a "nova compreensão" acerca do material analisado. Desta forma, a ATD

pode ser compreendida como um processo auto-organizado de construção de novos significados em relação a determinados objetos de estudo, a partir de materiais textuais referentes a esses fenômenos. Nesse sentido, é um efetivo aprender, aprender autoorganizado, resultando sempre num conhecimento novo (Moraes, \& Galiazzi, 2007, p.45).

Sendo assim, da análise das entrevistas realizadas, resultaram quatro categorias as quais mostram características das concepções e ações dos cinco sujeitos. Essas categorias foram denominadas de: 1) O desenvolvimento dos trabalhos: contextos e concepções; 2) Pressupostos freireanos como balizadores das concepções e práticas; 3) Elementos relacionados à perspectiva da AT; e 4) Desafios: como tentar superá-los?.

Entretanto, no texto que segue, serão apresentadas e discutidas apenas as três primeiras categorias. A categoria “iv) Desafios: como tentar superá-los?”, apesar de reunir elementos que apontam como os pesquisadores trabalham com a $\mathrm{AT}$, não será objeto de discussão pois já foi apresentada em trabalho anterior (Magoga, \& Muenchen, 2017) e está descrita em Magoga (2017).

Mesmo assim, descrevendo-a brevemente, a categoria "Desafios: como tentar superá-los?” é composta por unidades de significado que representam, na visão dos entrevistados, os desafios associados ao trabalho a partir da AT, assim como elementos que possam ser repensados na tentativa de superação daqueles. Dos desafios, a principal característica deve-se ao fato que eles sempre versavam a composição dos processos formativos, principalmente a formação inicial, de modo que há a necessidade de discussões mais profundas dos que às do campo curricular, implicando em discussões de políticas públicas.

\section{Resultados e discussões}

Na sequência do texto, a partir das três categorias mencionadas anteriormente, serão apresentadas características dos pensamentos e ações desenvolvidas pelos sujeitos entrevistados.

Acrescenta-se, também, que as categorias "2) Pressupostos freireanos como balizadores das concepções e práticas" e "3) Elementos relacionados à perspectiva da AT", são compostas por três subcategorias, cada uma. Essas subcategorias foram identificadas pois, apesar de reunirem elementos comuns à grande categoria, são compostas por um maior detalhamento de características. 


\section{1) O Desenvolvimento dos trabalhos: contextos e concepções}

A primeira categoria identificada pelo processo de ATD refere-se, como a própria denominação sugere, ao modo como, onde e com quem os sujeitos identificados desenvolvem os trabalhos relativos à AT.

Apesar de trabalharem em distintas universidades, os pesquisadores possuem algumas características comuns, sendo que a principal delas refere-se à concepção da perspectiva de AT que eles mais se identificam: a freireana.

A identificação pela perspectiva da Abordagem Temática Freireana (ATF) justifica-se por diferentes motivos, dentre os quais, está a mudança do status quo - tanto do sujeito como do contexto - possibilitada por ela. Para os professores P3 e P5:

Então, eu trabalho mais com a abordagem temática freireana, por que eu acho que ela vai mais ao encontro da perspectiva educacional que eu quero desenvolver e que eu quero trabalhar na formação inicial. Então, eu quero que os meus alunos consigam se apropriar pelo menos de alguns elementos, de alguns pressupostos, porque eu avalio que ela dá conta de pensar a transformação da escola (P3).

Eu trabalho mais com a abordagem temática freireana. Porque tem toda uma questão histórica por trás disso, tem todo o envolvimento meu com essa abordagem temática freireana, e também porque eu acho que ela realmente que vai trazer à tona um tema que vai ter sentido e significado tanto pro aluno quanto pro professor que vai trabalhar (P5).

Aliado também a essa perspectiva freireana de AT, percebeu-se algumas singularidades de cada sujeito, especialmente dos pesquisadores P1, P2 e P4. Apesar de também partilharem dos pressupostos da ATF, eles explicitaram que trabalham à sua maneira com essa perspectiva. Para P2, por exemplo, a perspectiva da ATF é fundamental no trabalho com as questões ambientais.

[...] eu tenho uma perspectiva da abordagem temática freireana porque eu acho que tem que ter uma aproximação do sujeito e do contexto social, e eu acho que a questão ambiental é fundamental nisso. E é peculiar, porque a questão que eu trabalho é a questão socioambiental (P2).

Já o professor P1 considera que ATF, pode ser complementada com contribuições do campo Ciência-Tecnologia-Sociedade ou, mais especificamente, do Pensamento Latino Americano em Ciência, Tecnologia e Sociedade (PLACTS).

$\mathrm{Eu}$ me identifico mais com, quer dizer, bastante com a perspectiva da abordagem temática freireana. Porque? Pela concepção política que a fundamenta [...]. Contudo, não desconsidero contribuições também da abordagem por temas, usa-se menos abordagem temática, mas abordagem por temas de CTS, considerando que Freire aprofunda pouco a discussão sobre ciência-tecnologia [...] Então, quer dizer, eu tenho trabalhado nessa perspectiva freireana, mas o campo CTS e o campo do pensamento latino americano CTS potencializam, aprofundam, aquilo que Freire, parece-me não aprofundou suficientemente (P1). 
Também sobre as contribuições do campo CTS à perspectiva da ATF, o professor P4, criticamente, identifica-se como diferente em relação a outros grupos que trabalham com esse viés. Em suas palavras,

Eu tenho trabalhado com a aproximação Freire-CTS. Talvez numa linha um pouco diferente do que vem sendo trabalhado pelo grupo do Rio Grande do Sul, porque eu não tenho investido tanto na realização da investigação temática (P4).

Torna-se essencial destacar que uma das características da ATF está justamente no modo da busca pelo tema. Baseando-se em Freire, nos trabalhos via ATF é natural que os envolvidos realizem o processo de Investigação Temática (Freire, 1987), na busca de elucidar as chamadas situações-limite. Estas situações constituem o núcleo pedagógico/ curricular a ser desenvolvido nos processos educativos, como se abordará - de modo mais sistemático - nas próximas categorias.

Outro aspecto relevante dessa categoria refere-se aos contextos de trabalho dos sujeitos identificados. Quando se coloca “contextos de trabalho", não se deseja remeter ao local, "espaço físico", mas às formas nas quais os trabalhos e as experiências, a partir da AT, vêm sendo desenvolvidas.

Nesses contextos, são percebidas tendências principalmente relativas às formações iniciais e continuadas, além da importância dos grupos e de trabalhos com outros setores das universidades.

Primeiramente, sobre as formações iniciais, percebeu-se que todos os professores/ pesquisadores lecionam em cursos/graduações de Física ou que tenham potenciais licenciados em Física, como, por exemplo, o curso de Ciências da Natureza. Essa constatação está relacionada ao fato de que todos esses professores/pesquisadores, da mesma forma, possuem formação inicial em Física Licenciatura Plena. Esse resultado pode possuir raízes históricas com as discussões de Pierson (1997), até mesmo porque, durante as entrevistas, observou-se que alguns professores foram orientados por membros do Grupo de Reelaboração de Conteúdo e Formação de Professores (Magoga, 2017).

Nesses cursos de graduação onde os entrevistados trabalham, eles relataram lecionar disciplinas tanto teóricas, como "Didática", quanto práticas, relacionadas aos "Estágios"

Então eu dou um curso de didática que tem alunos, potenciais alunos da engenharia, potenciais alunos da física, potenciais alunos da licenciatura. Então eu aponto coisas sobre a abordagem temática. Eu tenho lá duas aulas que é voltada a Paulo Freire, e aí eu falo da abordagem freireana e até trago as outras perspectivas, mas ela é menos aprofundada do que no grupo ou das aulas que eu conseguiria, que eu dou, por exemplo, de práticas de ensino, que aí eu consigo trabalhar (P2).

Então na graduação eu não direciono, eu não trabalho com abordagem temática especificamente, eu apresento essas três perspectivas, embora eu acho que possam ter outras, eu acredito que essas são, até agora, as que mais se caracterizam como abordagem temática, eu trabalho com elas na graduação (P5). 
$\mathrm{Na}$ fala de P5 é possível perceber a menção à três perspectivas de AT, sejam elas: "ATF, AT na perspectiva Ciência-Tecnologia-Sociedade e AT na perspectiva da Situação de Estudo". Essas serão focos de análises na categoria "Elementos relacionados à perspectiva da $\mathrm{AT}$ ".

Sobre o "grupo" citado por P2, identificou-se que eles são espaços os quais todos entrevistados vivenciam, e são formados, basicamente, por professores da rede básica, pós-graduandos e alunos de iniciação científica das mais diferentes áreas.

O nosso grupo é formado por mestrandos, voluntários, e alunos de iniciação científica. Os alunos de iniciação científica, eu tenho dois da física. Voluntários eu tenho professores da educação básica aqui da rede estadual e particular [...] E aí a gente tem alunos de pós-graduação, também, né [...] Então nosso grupo tem química, física, biologia e pedagogia. Estamos tentando garimpar uma da geografia [...] E então a gente trabalha, a gente tem uma discussão mais teórica e uma parte mais prática (P5).

Mas as pessoas que você menciona, várias delas, elas trabalharam comigo para além do campo da física, se envolveram em projetos [...] Então você tinha projetos de iniciação científica, havia orientações de mestrado, eu também trabalhei na pedagogia, com uma abordagem temática (P1).

Vale destacar ainda o "papel" desses grupos como espaços formativos, pois neles ocorrem discussões e ações mais profundas sobre a perspectiva da AT, especialmente a freireana.

Constituir um grupo permite um maior trânsito de ideias, de trocas, de compartilhamento, de entender o outro como sujeito. Em outros termos, a constituição de um grupo perpassa pela afirmação do coletivo, respeitando as singularidades de cada sujeito, educando e educador. Em contrapartida, para Freire (1987; 2011a), o processo educativo deve ser problematizador e dialógico, o que indica que ambos os sujeitos, educador/educando e educando/educador, aprendem enquanto ensinam e ensinam enquanto aprendem, não devendo haver preconceito ou qualquer tipo de discriminação durante tal processo, como é o possibilitado pelo coletivo.

Os grupos são, portanto, espaços de estudos e pesquisas, auxiliando também no desenvolvimento de processos formativos para educadores da educação básica. Aliás, os processos formativos são outro importante contexto de atuação dos sujeitos investigados.

Essas que eu mencionei elas foram todas para o ensino médio. Porque eu não trabalho pro ensino, pelo menos não to trabalhando com o ensino fundamental. Até a gente tem uma orientanda que estava afim de fazer isso, mas no geral meu foco é o ensino médio, e também na formação de professor. Então acho que sempre aparece quando a gente vai dar algum curso e tal (P2).

É, e talvez na linha da formação continuada... Enfim. Também tem outras ações, né, porque tem alguns cursos de extensão que a gente tem desenvolvido [...] Então eu acho que são contextos variados desde discussões que são mais teóricas até mais práticas de orientação, de colaboração com os professores na elaboração e desenvolvimento de 
propostas em sala de aula, de intervenções pontuais (P4).

Percebe-se, com isso, que as concepções teóricas e os contextos de trabalhos dos sujeitos pertencentes ao círculo esotérico identificado são muito próximos e, em certo sentido, semelhantes.

\section{2) Pressupostos Freireanos como balizadores das concepções e práticas}

A categoria denominada de "Pressupostos Freireanos como Balizadores das concepções e práticas" visa apresentar e discutir como elementos da perspectiva freireana aparecem ou são utilizados pelo coletivo de pesquisadores P1, P2, P3, P4 e P5. Como se pôde perceber, há grande referência à ATF, de modo que os professores identificam-se com essa modalidade. Neste sentido, questiona-se: como essa ATF vem auxiliando as experiências desenvolvidas?

Com o intuito de responder ao questionamento proposto, a presente categoria divide-se em três sub- categorias: a) Processos Formativos Baseados em Freire; b) Ações Balizadas pelas Demandas da Realidade; c) ATF: A realidade entendida a partir da práxis.

\section{a) Processos formativos balizados em Freire}

A primeira subcategoria identificada reúne discussões relativas aos processos formativos desenvolvidos pelos sujeitos entrevistados. Tais ações formativas, como apresentado na categoria anterior, ocorrem tanto no âmbito da formação inicial como continuada, e têm como característica discussões das proposições de Freire, ou da ATF.

O principal foco de discussões, nessas formações, está baseado no estudo e nas ações envolvendo o processo de Investigação Temática (Freire, 1987), como explicitado nos seguintes extratos:

Então, nessa disciplina de saberes e fazeres eu trabalho com os alunos os pressupostos da abordagem temática, eu caracterizo a abordagem temática, a investigação temática, todas as etapas com eles, levo exemplos, trabalho um pouquinho também o que o Gouvêa traz mais que é da fala significativa [...] Durante o estágio os alunos implementam isso. Então, no estágio que eu oriento, eles fazem a investigação da realidade. No primeiro estágio eles fazem o processo de investigação, até a etapa de chegar em um tema gerador, pelo menos a última vez foi assim agora. E no segundo estágio a gente faz a redução temática e a implementação em sala de aula. Então é um trabalho de um ano inteiro com eles, começando com o estudo da proposta, e depois fazendo a investigação da realidade, fazendo o processo de análise das falas significativas (P3, grifo nosso).

Quando a gente desenvolve esses processos de formação de professores, a gente faz todo um processo de investigação temática junto com outros professores. Então vem desde o levantamento preliminar até o desenvolvimento, elaboração das aulas e implementações das aulas, é sempre em colaboração do grupo com os professores (P5, grifo nosso). 
As unidades de significado apresentadas representam os preceitos dessa categoria, pois evidenciam que, tanto na formação inicial (como descrito por P3) quanto na formação continuada (explicitado por P5), há clara importância dos conceitos e dos pressupostos freireanos como balizadores desses processos.

Ademais, os aspectos derivados dos diálogos com os pesquisadores entram em consonância com algumas características observadas em alguns trabalhos presentes na literatura da área, como, por exemplo, no trabalho de Gehlen, Strieder, Caramello, Feistel, e Halmenschlager (2014), em que, "Tendo como pano de fundo essas discussões, o terceiro foco da disciplina de "Prática de Ensino de Física I" envolveu o estudo de algumas propostas, para além da perspectiva freireana (Delizoicov, Angotti, e Pernambuco, 2002; Silva, 2004), que têm como referência a Abordagem Temática" (p. 222).

Outra evidência à perspectiva de Freire também é identificada no trabalho de Muenchen e Auler (2007), em que a ação relativa à formação de professores foi balizada "por uma articulação entre pressupostos do educador brasileiro Freire (1987) e referenciais do denominado movimento Ciência-Tecnologia-Sociedade (CTS), articulação iniciada por Auler (2002)" (p. 422).

Entende-se que realizar processos formativos com base em pressupostos freireanos é reafirmar o protagonismo dos educadores que, sujeitos, são seres existenciais e históricos; isto é, processos formativos a partir do viés freireano possibilitam aos sujeitos a problematização de suas realidades não a partir do olhar do "formador", mas do olhar próprio de cada um dos educadores/sujeitos. Neste sentido, para Freire (1987), "a educação autêntica, repitamos, não se faz de A para B ou de A sobre B, mas de A com B, mediatizados pelo mundo" (p. 84).

Ainda sobre a significação dos processos formativos baseados em ideais freireanos (Freire, 2011a), percebe-se que eles também proporcionam a horizontalidade entre os sujeitos envolvidos, o que é ressaltado com a condição de que "quem ensina aprende ao ensinar e quem aprende ensina ao aprender" (p.47).

Destaca-se também o potencial formativo presente no próprio processo de Investigação Temática, citado pelos professores do círculo esotérico, pois ele exige a constante pesquisa, estudo e diálogo entre pares, em todas as etapas, desde o levantamento preliminar até a redução temática, quando se organizam - de maneira interdisciplinar - os planejamentos de aulas. Assim, a categoria freireana de "pesquisa" é algo constante nas ações balizadas pelos especialistas do círculo esotérico identificado, pois, para Freire (2011a), "não há ensino sem pesquisa e pesquisa sem ensino. Esses quefazeres se encontram um no corpo do outro" (p. 30-31).

Os processos formativos realizados pelos pesquisadores também encontram semelhanças com algumas ações realizadas no Projeto Interdisciplinar Via Tema Gerador, ocorrido em São Paulo/SP, quando Freire foi secretário de educação. Naquela ocasião, assim como explicitado pelas unidades de significado, também houve formações que se diluíam em estudos teóricos e ações práticas, envolvendo principalmente o Estudo da Realidade das comunidades de cada escola (São Paulo, 1990; 1992). 
De acordo com Garcia, Martinelli e Moraes (1993), eram princípios básicos do "Projeto Inter"

o educador é o sujeito de sua prática e cabe a ele criá-la e recriá-la; a formação do educador deve privilegiar a reflexão sobre o seu cotidiano, instrumentalizando-o para a necessidade de criar e recriar sua prática pedagógica; [...]; um educador aprende com o outro, e o grupo é o espaço por excelência de aprendizagem dos indivíduos; há saber na fala dos educandos e os educadores têm na sala de aula parte do seu universo de pesquisa e aprendizagem (p. 206).

Percebe-se, pela passagem anterior, que vários dos princípios relacionam-se com algumas características identificadas em trabalhos da área e, principalmente, nas ações dos pesquisadores entrevistados. Essas características serão aprofundadas nas próximas subcategorias e categoria.

\section{b) Ações balizadas pelas demandas da realidade}

A subcategoria anterior é composta por elementos que mostram a estreita relação entre a perspectiva freireana e os processos formativos realizados com educadores tanto da modalidade inicial como continuada/permanente. Essa estreita relação deve-se ao fato de que as formações contêm discussões e são organizadas a partir de elementos de Freire, embasadas em ideais dialógicos, problematizadores e teórico-práticos-reflexivos.

Na presente subcategoria, registram-se elementos os quais mostram que as ações derivadas dos processos formativos, ou até mesmo de outra natureza, como os trabalhos desenvolvidos em pesquisas ou em contextos de grupos, levam em conta ou são oriundos de demandas das realidades locais dos sujeitos aos quais essas ações referem-se.

Assim sendo, o desenvolvimento dos trabalhos realizados nas formações ou nos contextos de grupos - o que não deixa de ser "formação", mas é diferente no sentido espaço-temporal de um curso, de uma atividade de extensão, por exemplo - carregam elementos da perspectiva freireana, pois giram em torno de problemas, contextos e contradições das comunidades, como exemplificado nas unidades que seguem:

[...] Nós estamos trabalhando na identificação de demandas da comunidade local, regional, e essas demandas elas são pensadas na perspectiva de tanto alimentar projetos de pesquisa na universidade, quanto a dimensão do ensino (P1, grifo nosso).

E os alunos lá eles traziam, eu pedi pra que eles montassem propostas nessa perspectiva da abordagem temática e foi muito legal, porque eles trouxeram problemas da comunidade mesmo (P2, grifo nosso).

Durante o diálogo com os pesquisadores, além dos relatos relativos às ações, foi possível perceber que eles compreendem que o trabalho a partir da realidade local é uma marca da perspectiva freireana de AT.

Então ela [ATF] permite isso, essa aproximação eu acho de, até nos próprios princípios da abordagem temática, os pressupostos freireanos também. Primeiro a aproximação de olhar pra esse aluno, olhar pra esse contexto e trabalhar a partir desse contexto 
(P3, grifo nosso).

Propor, pensar um outro currículo. Um currículo que esteja, que tenha como eixos, que esteja articulado em torno de temas, de problemas oriundos da comunidade. Essa é a questão central, no meu entender, da abordagem temática [...] Aqui eu estava falando da perspectiva freireana (P1).

De acordo com Schneider, Centa e Magoga (2015) a ATF carrega vários elementos de Freire, desde o diálogo e a problematização (que não são quaisquer) até o processo de obtenção de temas geradores pela Investigação Temática (Freire, 1987) ou, mais recentemente, pelos 3MP como estruturantes de currículos (Araújo, 2015; Centa, \& Muenchen, 2016; Muenchen, 2010).

Para Freire, (1987), a Investigação Temática "insere ou começa a inserir os homens numa forma crítica de pensarem seu mundo” (p. 97). Ainda para o autor,

Investigar o tema gerador é investigar, repitamos, o pensar dos homens referido à realidade, é investigar seu atuar sobre a realidade, que é sua práxis. A metodologia que defendemos exige, por isto mesmo, que, no fluxo da investigação, se façam ambos sujeitos da mesma - os investigadores e os homens do povo que, aparentemente, seriam seu objeto (Freire, 1987, p. 98).

Acrescentando a essa discussão dos sujeitos envolvidos no processo de Investigação Temática, Torres (2010, p. 191) explicita que "a Abordagem Temática pautada em temas geradores permite que educandos e educadores se tornem sujeitos ativos do processo de ensino e aprendizagem, uma vez que ambos participam do processo de investigação e redução dos temas geradores de currículos críticos”.

Elementos sobre a Investigação Temática Freireana também são sinalizados e desenvolvidos em alguns trabalhos da literatura da área. No entanto, na maioria desses trabalhos não são realizadas todas as etapas da Investigação Temática, sistematizadas por Delizoicov (1991), mas são feitas "releituras de Freire", como explicitado por Gehlen et al. (2014), no trabalho com licenciandos, em que "há um reinventar nas propostas dos referenciais realizada em função de alguns limites na formação inicial de professores e na Educação Básica” (p. 234). Na referida ação, por exemplo, foram realizadas apenas a primeira e quarta etapa do processo de Investigação Temática.

Independentemente da realização de todas ou de partes das etapas sistematizadas por Delizoicov (1991), decorrentes do processo de Investigação Temática, o que torna essa subcategoria significativa é o fato dos pesquisadores balizarem as suas ações $a$ partir das demandas e dos problemas reais vividos por determinadas comunidades. Essa é, sem dúvida, a principal marca da perspectiva freireana à qual eles dizem identificarse. Assim sendo, trabalhar com esse viés é problematizar o que Freire (1987) denomina de "situação-limite". Em suma, para Gehlen (2009), uma "situação-limite" expressa uma contradição real e significativa de determinada comunidade de sujeitos, os quais, inacabados e inconscientes, não percebem como uma contradição, mas como certo "fatalismo", pré-concebendo tais situações como oriundas de "destino dado". 
De acordo com Freire (1987; 2011a; 2011c), os sujeitos - pode-se pensar, por exemplo, educadores e educandos - são seres de práxis, o que lhes possibilita superar tais "situações-limites", em voga do denominado "inédito viável". Por ser um ser de práxis, portanto, somente o Homem, um sujeito reflexivo-ativo, consegue criar e recriar a sua própria realidade, através de uma intervenção consciente, o que possibilita dizer que somente o homem é capaz de transformar a sua realidade. Esse é, aliás, o principal aspecto da próxima sub-categoria.

\section{c) ATF: a realidade entendida a partir da práxis}

A subcategoria "ATF: a realidade entendida a partir da práxis" reúne unidades de significado que remetem à ATF, especialmente sobre a importância dos conteúdos trabalhados por ela para a participação e consequente transformação social, por parte dos sujeitos envolvidos.

Freire sempre foi um educador/epistemólogo que via o processo educativo, além de um ato de conhecimento, como um ato político e, por isso mesmo, percebia que a educação pode ser tanto mantenedora de um status quo ou de carregar elementos para a transformação social. Segundo Guerrero (2010), no entender de Freire, “os sujeitos são chamados a analisar criticamente um objeto determinado de estudo para que ao conhecêlo, possam atuar sobre ele transformando-o e transformando a si mesmos" (p. 79).

É sobre essa percepção, portanto, que se assentam as considerações acerca do "papel da ATF”, pois, para P1,

[...] a perspectiva freireana, numa abordagem temática, ela tem esse plano de fundo, esse horizonte de transformação social. Isso muitas vezes é esquecido e até ignorado quando se trabalha com a abordagem temática freireana. Não necessariamente todas as outras vertentes de abordagem temática trabalham com essa perspectiva mais política, todas elas são políticas, nenhuma é neutra, mas Freire explicitamente trabalha a perspectiva política de transformação do status quo, e não a sua perpetuação ( $\mathrm{P} 1$, grifo nosso).

A questão da transformação da realidade aparece também acoplada a outro conceito freireano, que é o de participação. Marca central no Projeto Interdisciplinar Via Tema Gerador, a participação sempre foi vista como uma característica do processo educativo freireano (Saul, \& Silva, 2009) e está relacionada tanto com o diálogo quanto implica a transformação.

Ambas as questões, da participação e da transformação, foram identificadas em todos os diálogos com os pesquisadores, mas sempre remetendo à ATF, seja em trabalhos relacionados a cursos de formação inicial ou continuada. Sobre isso, apresentam-se os seguintes extratos significativos

Então, é a questão do compreender realmente qual é a realidade que eles tão vivendo e também desperta a questão da participação deles na sociedade. Então é o despertar para a cultura de participação, romper com a cultura do silêncio. Então tem um pouco dessa questão envolvida aí. E isso pra nós fica muito claro, principalmente quando a gente 
desenvolve os cursos de formação de professores (P5).

Então, eu acho que é essa perspectiva de leitura crítica da realidade. Como a gente tem trabalhado com a abordagem temática a partir da seleção de um tema que está associado ao contexto, à realidade dos alunos, e a partir disso trabalha os conhecimentos científicos, então vem muito nessa linha, de uma ação, de compreensão da realidade, de transformação (P4).

A “cultura do silêncio", descrita por P5, já vem sendo denunciada e discutida na própria área de ensino de ciências com uma ênfase maior. Observa-se, por exemplo, que os trabalhos de Auler (2003) e Muenchen e Auler (2007), já destacam e defendem que a AT é um dos possíveis meios para a superação dessa.

Também defensoras de uma "cultura de participação", em contraposição a uma "cultura do silêncio", Centa e Muenchen (2016) entendem que a participação dos sujeitos - educandos e educadores - pode ocorrer desde a investigação do Tema Gerador. Associado a isso, a participação desses sujeitos também é observada pela sua maior motivação, seja na sala de aula, ou no planejamento curricular - algo semelhante ao defendido por Giacomini, Magoga e Muenchen (2013). Ainda, para as autoras,

O tema da realidade dos educandos apontou possibilidades de uma cultura de participação e provocou, tanto nos educadores quanto nos educandos, maior motivação na sala de aula. A problematização da situação-limite permitiu aos educandos compreensões do mundo em que vivem, relacionadas ao desenvolvimento de um nível mais crítico de conhecimento e da sua realidade. A motivação em aprender deu-se na mesma intensidade em que surgiu o estímulo para superar a situação-limite (Centa, \& Muenchen, 2016, p. 282).

Outro ponto crucial para o entendimento dessa subcategoria (ATF: a realidade entendida a partir da práxis) deve-se ao fato de que a práxis - ação-reflexão-ação possibilitada pela participação reflexiva e consciente na realidade, só acontece graças ao papel dos conceitos científicos, dentro dessa perspectiva de AT e defendida pelos pesquisadores. Para P2, a ATF“[...] dá a oportunidade do outro falar, sem ter que falar só a partir da linguagem ou da perspectiva da física, mas da física também. Porque pra gente discutir isso é fundamental" (P2).

A importância dos conceitos científicos também é ressaltada, explicitamente, no sentido da participação e transformação social.

Eu acho que esse seria o papel do conceito nessa proposta. De fazer com que o aluno tenha condições de entender melhor a situação como um todo, de tomar, de se posicionar criticamente em relação a isto, de tomar suas decisões e transformar sua realidade (P3).

E a questão da apropriação do conceito, a gente quer isso também, a gente quer que o aluno se aproprie do conceito científico, e também da questão da participação ativa desse sujeito dentro da comunidade (P5).

Em certo sentido, observa-se que o papel dos conceitos científicos na ATF é 
funcional e derivado do processo de Investigação Temática, pois não é qualquer conceito científico que dá conta de pensar e auxiliar na superação das situações-limites préidentificadas pelo conjunto de especialistas e educadores.

Em suma, a característica identificada nessa sub-categoria carrega elementos freireanos fundamentais, que são os de práxis e transformação. Observou-se que, para os especialistas entrevistados, o processo educativo é balizado no viés freireano e que ele deve ser organizado para que os sujeitos $1^{\circ}$ ) de posse dos conhecimentos científicos $2^{\circ}$ ) possam aprender e participar $3^{\circ}$ ) e, participando, possam problematizar e transformar as suas realidades. Essa é, com certeza, a fundamentação que está por trás da formação de todo e qualquer sujeito crítico, prevista na Lei de Diretrizes e Bases (Lei n. 9394, 1996).

\section{3) Elementos relacionados à perspectiva da AT}

A terceira categoria, denominada "Elementos relacionados à perspectiva da AT", reúne elementos que são relativos à perspectiva curricular da AT e não a uma modalidade/ perspectiva específica de AT, como, por exemplo, a freireana ou a de enfoque CTS.

A partir da análise realizada, após a entrevista com os professores, identificou-se que - além da forte tendência freireana - eles guardam elementos similares em relação à concepção de currículo escolar, na perspectiva da $\mathrm{AT}$, à importância dos sujeitos (educandos e educadores), assim como ao trabalho interdisciplinar - entendido também como um desafio.

Todos esses elementos serão discutidos na sequência, ao longo de três subcategorias: "d) AT: princípios e modalidades"; “e) Aprendizagem do educando enquanto sujeito do processo educativo"; "f) Trabalho interdisciplinar".

\section{d) AT: princípios e modalidades}

$\mathrm{O}$ primeiro aspecto relacionado à perspectiva da AT envolve justamente a concepção, por parte dos integrantes do círculo esotérico, acerca do "o que é essa AT?". Sobre essa questão, todos foram enfáticos: é uma perspectiva de conceber o currículo a partir de temas. No entanto, esse tema a que os pesquisadores referem-se não é "qualquer tema", pois "Na linha da abordagem temática, como eu vejo como um aspecto principal, o tema é central, e o conhecimento científico, o conteúdo, é um meio para entender esse tema" (P4). Ainda, "pra mim abordagem temática é essa perspectiva curricular em que eu tenho uma subordinação dos conceitos/conteúdos a um determinado tema" (P5).

As falas representadas carregam semelhanças com a definição de AT, disseminada principalmente pelo livro Ensino de Ciências: fundamentos e métodos: "perspectiva curricular cuja lógica de organização é estruturada com base em temas, com os quais são selecionados os conteúdos de ensino das disciplinas. Nessa abordagem, a conceituação científica da programação é subordinada ao tema" (Delizoicov, Angotti, \& Pernambuco, 2011, p. 189).

A subordinação do conceito ao tema impõe outro olhar para o currículo escolar 
e, como consequência, ao processo educativo. Esse olhar, de acordo com Centa et al. (2015), pode contribuir no debate de questões sociais, éticas, políticas, econômicas, dentre outras, auxiliando na formação de sujeitos críticos. Ressalta-se, mais uma vez, que essa concepção de currículo enaltece o sujeito e opõe-se a uma prática e concepção determinística, acrítica e subalterna, como a derivada de uma educação bancária (Freire, 1987).

Quando se trabalha a partir da lógica de que os conceitos científicos não estão dados, mas que são definidos a posteriori à temática, possibilita-se a autonomia do educador como sujeito crítico. Ademais, esse "outro olhar" sobre o currículo escolar intrínseco à AT - não é algo que está dado, ou sequer é recorrente nas escolas brasileiras, e permite estabelecer que "[...] é, óbvio, que pra você trabalhar na perspectiva da abordagem temática, você vai ter que fazer escolhas. E fazer escolhas significa brigar com o sistema (P2)".

Ao longo dos diálogos com os professores, surgiram outros elementos que possibilitam perceber características dos modos de pensar e agir. Outro desses elementos abrange a concepção sobre as principais perspectivas, também entendidas como modalidades, de AT.

Observando as concepções dos entrevistados, nota-se a recorrência de três perspectivas: AT Freireana, AT na perspectiva CTS e AT na perspectiva da SE. Essa compreensão advém de algumas falas significativas, como, por exemplo, as seguintes:

Então, tem essas diferentes perspectivas, tem CTS, tem a abordagem temática freireana, tem a situação de estudo, tem as questões sociocientíficas, todo esse conjunto que faz uma organização a partir de temas. Mas alguns deles tem uma ênfase curricular maior, outros menor (P4).

[...] que é a abordagem temática e aí vem as perspectivas, dentro da linha de CTS, a abordagem temática na perspectiva ciência-tecnologia-sociedade, abordagem temática freireana, que aí, da forma como a gente trabalha aqui, a gente faz o processo de investigação temática, tenta fazer o processo de investigação temática pra se chegar ao tema gerador, e também tem a perspectiva da situação de estudo. Então eu vejo essas, no ensino de ciências, como as principais perspectivas que trabalham a abordagem temática (P5).

A identificação dessas perspectivas também ocorre vem sendo percebida em trabalhos dentro da área de educação em ciências, como em Magoga et al. (2015). Tratando dessas perspectivas, Hunsche e Delizoicov assinalam que

Várias propostas educacionais que buscam a organização curricular com base em temas são encontradas na literatura sobre o ensino de Ciências, dentre as quais se destacam a Abordagem Temática de inspiração freiriana (Delizoicov; Angotti; Pernambuco, 2002; Delizoicov, 2008), a Situação de Estudo (Maldaner; Zanon, 2001; Maldaner, 2007), a Abordagem Temática com referenciais ligados ao movimento CiênciaTecnologiaSociedade (CTS) (Santos; Schnetzler, 1997; Auler, 2002; Garcìa; Cerezo; Luján, 1996; Santos; Mortimer, 2000), além da proposta que aproxima referenciais freirianos com os 
ligados ao movimento CTS (Auler, 2002) (Hunsche, \& Delizoicov, 2011, p. 2).

Desta maneira, admite-se que os principais elementos dessa subcategoria indicam como os especialistas concebem a AT e as suas principais modalidades. Na sequência, serão discutidos outros elementos os quais reiteram a visão dos entrevistados.

\section{e) Aprendizagem do educando enquanto sujeito do processo educativo}

"Mas de forma geral, todas elas tão preocupadas em colocar o aluno como sujeito do conhecimento [...], isso é uma características delas de colocar o aluno como participativo no processo de aprendizagem, não como um mero receptor de informações"(P3).

A unidade de significado exposta representa exatamente o aspecto central dessa categoria, que é o de discutir a visão dos pesquisadores em relação ao processo de aprendizagem dos sujeitos (educandos e educadores), quando se trabalha via AT.

Delizoicov, Angotti e Pernambuco (2011), na obra magna referente à AT, entendem o educando, através das mesmas palavras utilizadas por P3, como "sujeito do conhecimento". Em tal livro, "Ensino de Ciências: fundamentos e métodos", os autores dedicam um capítulo inteiro a essa discussão e explicitam que "o aluno em questão é o sujeito da própria aprendizagem [...] É portador de saberes e experiências que adquire constantemente em suas vivências" (Delizoicov, Angotti, \& Pernambuco, 2011, p. 152).

Entender o aluno como "sujeito do conhecimento", "sujeito de sua própria aprendizagem", ou simplesmente como "sujeito", significa entender que ele não é um vasilhame a ser preenchido à medida que o educador simplesmente narra fatos (Freire, 1987). Baseada em pressupostos freireanos, Lindemann (2010) também defende o educando como "sujeito do conhecimento", o qual "é entendido como um ser inacabado e inconcluso que, ao perceber-se assim, busca ser mais" (p. 168).

No extrato que iniciou essa categoria, o pesquisador P3 expõe que a questão o educando como "sujeito do conhecimento" é uma característica de todas as perspectivas de AT.

Atrelada à questão do "sujeito da aprendizagem" está justamente a própria aprendizagem desse sujeito, possibilitada pelo processo educativo do qual a AT é promotora. Sobre tal fato, P2 afirma que

[...] você sempre acha que "ah, ele vai aprender um pouquinho mais". Cara, não é isso. Eles aprendem efetivamente muitas coisas interessantes. Ainda que no meio do caminho ele largue algumas coisas, e é normal, assim. Ele volte a um pensamento que era inicial, é normal, e que bom que é assim. Então é muito legal essa perspectiva. [...] Mas é muito rico. Isso é muito legal (P2).

Giacomini, Magoga e Muenchen (2013) ressaltam que, ao trabalhar com a AT, é possível perceber uma maior participação dos educandos, possibilitada pela motivação do estudo do tema e dos conceitos científicos. A essa maior participação, segundo os autores, está relacionado um maior aprendizado, derivado justamente do estudo daqueles conceitos. 
Assim como no trabalho de Giacomini, Magoga e Muenchen (2013), na ação descrita por Sousa, Bastos, Figueiredo, e Gehlen (2016), também foi possível perceber que a aprendizagem de conhecimentos científicos possibilitou o entendimento de outros conhecimentos relacionados ao mundo dos educandos. Em certo sentido, considerar o aluno como sujeito do conhecimento envolve a discussão das relações entre a leitura de mundo e leitura da palavra, pois os sujeitos, de posse dessa última, podem realizar a leitura daquele (Freire, 2011b).

Ademais, outra potencialidade da AT como promotora da aprendizagem também é percebida no trabalho de Oliveira e Langhi (2014). Para eles, "adequando-se às premissas da perspectiva freiriana, as discussões ocorridas com o grupo de alunos sobre as questões sociais locais permitiram suas manifestações, tomadas de consciência e incentivo à ação" (p. 667).

Considerar, portanto, o educando como sujeito da aprendizagem reflete em considerar o educador - que também, em muitos casos, é educando - do mesmo modo. Assim, para Delizoicov, Angotti e Pernambuco,

(...) a sala de aula passa a ser espaço de trocas reais entre os alunos e entre eles e o professor, diálogo que é construído entre conhecimentos sobre o mundo onde se vive e que, ao ser um projeto coletivo, estabelece a mediação entre as demandas afetivas e cognitivas de cada um dos participantes (Delizoicov, Angotti, \& Pernambuco, 2011, p. 153).

Percebe-se que as discussões aqui realizadas possuem certa aproximação com a subcategoria "ATF: a realidade entendida a partir da práxis", mas a diferença está no fato de que antes o foco era no potencial de participação e transformação da realidade, possibilitada pela ATF. Aqui, nessa categoria, o foco está muito mais na aprendizagem do educando que é o principal sujeito de sua aprendizagem.

\section{f) Trabalho interdisciplinar}

Outro importante elemento que está intrinsecamente relacionado à concepção curricular da AT é a interdisciplinaridade ou, expresso de outra forma, o trabalho interdisciplinar, no qual as diferentes componentes curriculares articulam-se para minimizar a tradicional fragmentação dos currículos escolares (Muenchen, 2006; Schneider, et al., 2014).

Sobre a asserção descrita no parágrafo anterior, o trabalho de Auler acrescenta que

Na perspectiva da abordagem temática, os temas, por se constituírem de situações amplas, complexas, permitem, requerem uma abordagem interdisciplinar, menos fragmentada. Pelo encaminhamento proposto, a interdisciplinaridade não se reduz a um relacionamento entre diferentes campos de conhecimento, a uma junção de disciplinas. O tema constitui-se no ponto em que as diferentes áreas do saber se relacionam interdisciplinarmente. Os temas, expressando fenômenos sociais complexos, remetem ao interdisciplinar. Sua compreensão requer vários campos de conhecimento, inclusive aqueles não restritos ao escopo das ciências naturais. Em síntese, o tema representa o 
ponto de encontro interdisciplinar das várias áreas do saber (Auler, 2003, p. 11, grifo nosso).

A concepção de que o tema, na perspectiva da AT, representa o ponto de encontro entre as diferentes áreas e disciplinas também se relaciona com as ideias de Freire (1987), quando define que o tema - no caso, gerador - entendido nas relações homens-mundo, é algo complexo pois carrega as contradições desses homens, em seus mundos, universos, contextos.

Apesar de - como se observou na categoria "Desafios: como superá-los?", discutida em Magoga (2017) - a interdisciplinaridade também ser um desafio, os sujeitos entrevistados identificam-na como fundamental, o que tende a justificar o fato dos grupos coordenados pelos especialistas - e descritos primeira categoria serem interdisciplinares, constituídos por físicos, matemáticos, geógrafos, pedagogos, biofísicos, químicos, biólogos, etc.

Para o professor P1, a interdisciplinaridade, dentro da perspectiva da AT, é importante porque:

Quando você identifica um tema e pensa em estruturar o currículo em torno desse tema, em torno de um problema que a comunidade vive, em geral se trata de um problema complexo aonde você tem várias variáveis envolvidas e você vai, para compreendê-lo, e se possível enfrentá-lo, você precisa do aporte de vários campos do conhecimento. Eu tenho usado a idéia de que os campos de conhecimento, as disciplinas, elas fazem um papel de luzes. Luzes que são jogadas sobre o problema. Então como o problema possui vários ângulos, então você precisa jogar várias luzes. Então nessa perspectiva o interdisciplinar, o multidisciplinar é fundamental ( $\mathrm{P} 1$, grifo nosso).

A descrição feita por P1 é bastante elucidativa e vai ao encontro da explanação realizada no início deste artigo, onde se descreveu a importância do diálogo e da problematização, associada ao trabalho interdisciplinar.

Para P1, um tema carrega várias e diferentes variáveis envolvidas, como, por exemplo, as dimensões políticas, sociais, econômicas, éticas - descritas por Centa et al. (2015) -, fazendo com que o diálogo e a problematização, a partir das diferentes disciplinas, não sejam uma imposição da AT, mas uma derivação natural dela. Expresso em outros termos, apenas uma disciplina não é capaz de "iluminar" todas as dimensões do tema, mas sem essa disciplina pode ser que o problema, o tema, deixe de ser visto em sua totalidade.

Acrescentando a essa discussão, Muenchen e Auler (2007) também defendem a intrínseca relação entre a AT e a interdisciplinaridade, pois, para eles, "a abordagem temática remete à interdisciplinaridade, considerando que a complexidade dos temas requer a análise sob vários ângulos, sob vários olhares disciplinares, constituídos de problemas abertos, sendo os problemas ambientais representantes típicos” (p. 4).

Caracteriza-se, com isso, que o trabalho interdisciplinar e coletivo é algo que o grupo de pesquisadores entrevistado compreende como fundamental e vinculado à própria perspectiva, no qual cada disciplina não perde a sua especificidade mas, ao 
contrário, compõe o todo. De certa forma, os resultados dessa subcategoria reafirmam que o tema desenvolvido pela AT não é algo estático, muito menos atemporal, ou permita-se o termo - "aproblemático". Por abarcar, portanto, diferentes contextos e problemas, o tratamento dado a tal tema requer, indubitavelmente, o "olhar" das diferentes disciplinas. Apesar de poder ser desenvolvido por apenas uma disciplina, um tema, na perspectiva da AT, não é disciplinar.

\section{Algumas considerações}

Como sinalizado ao longo deste trabalho, objetivou-se, a partir da análise de entrevistas realizadas com alguns dos principais professores/pesquisadores discutir características relativas às suas ações, tanto práticas quanto de pesquisa. Dessa forma, o modo de pensar e agir do coletivo, foi apresentado a partir de três categorias: 1) $\mathrm{O}$ desenvolvimento dos trabalhos: contextos e concepções; 2) Pressupostos Freireanos como balizadores das concepções e práticas; 3) Elementos relacionados à perspectiva da AT.

$\mathrm{Na}$ primeira categoria, denominada de $\mathrm{O}$ desenvolvimento dos trabalhos: contextos e concepções discutiram-se, essencialmente, os contextos de trabalho em que os sujeitos entrevistados realizam as suas ações, assim como a principal concepção teórica - perspectiva de AT - que eles dizem utilizar: a perspectiva da AT Freireana. Em relação a esses contextos, percebe-se grande ênfase aos processos formativos e aos trabalhos em contexto de grupos.

Já a categoria intitulada Pressupostos freireanos como balizadores das concepções e práticas emergiu devido ao fato de que todos os sujeitos, além de identificarem-se com a perspectiva freireana de AT, discorreram sobre elementos freireanos, os quais balizavam e/ou estavam subsidiando as ações práticas. Essa categoria, como se abordou, foi composta por outras três subcategorias: a) Processos formativos baseados em Freire; b) Ações balizadas pelas demandas da realidade; c) ATF: a realidade entendida a partir da práxis.

Através dos elementos apontados e discutidos nessa grande categoria (Pressupostos Freireanos como balizadores das concepções e práticas), pôde-se notar a forte influência do pensamento freireano no modo de pensar e agir dos sujeitos, sendo uma categoria fundamental para a caracterização do estilo de pensamento (Fleck, 2010) do coletivo.

Já em relação à categoria Elementos relacionados à perspectiva da $\mathrm{AT}$ foi possível discutir sobre a concepção de AT por parte dos entrevistados, assim como as suas concepções acerca da interdisciplinaridade. Ressalta-se, porém, que o aspecto mais significativo dessa categoria está associado à subcategoria "Aprendizagem de Educando enquanto sujeito do processo educativo", onde se percebeu que o papel do educando, nas ações com a AT, é de sujeito, participativo e que carrega concepções de mundo. Ademais, discorreu-se sobre o argumento de que a AT possibilita melhorar a aprendizagem dos indivíduos que são "sujeitos da aprendizagem". 
Como se comentou no início deste manuscrito, as características abordadas nas categorias possibilitaram identificar os elementos associados aos modos de pensar e agir, os quais compõem o Estilo de Pensamento compartilhado pelos professores entrevistados. A discussão mais aprofundada sobre este Estilo de Pensamento, envolvendo conceitos de Fleck (2010), é realizada no trabalho de Magoga e Muenchen (2018), em que o foco é o debate epistemológico articulado ao curricular.

Reitera-se que as caracterizações e discussões levantadas neste artigo fazem parte de uma pesquisa mais ampla e, por isso mesmo, tornam-se válidas na medida em que cumprem ao objetivo de contribuir de modo teórico e epistemológico para a área. As análises e sinalizações de como alguns sujeitos especialistas, professores/pesquisadores, entendem e trabalham com a AT, transcendem à simples replicabilidade prática e auxiliam na compreensão de novos caminhos e ações, em busca de uma educação comprometida, justa, de qualidade e solidária, através de reestruturações curriculares.

As discussões sobre os modos de pensar e agir são, portanto, fundamentais para que se possa compreender como está ocorrendo a construção e disseminação da perspectiva curricular da AT, a qual, como se discutiu, difere-se de uma abordagem por temas. Compreende-se, também, que as ações desenvolvidas pelos sujeitos entrevistados são construídas de modo coletivo, com outros sujeitos, professores, estudantes, pesquisadores, o que possibilita pensar que este Estilo de Pensamento deve estar sendo disseminado na área de ensino de ciências.

Dessa forma, sinaliza-se, como continuidade dessa pesquisa, a necessidade de um estudo que aborde como a circulação de ideias e práticas é vista e entendida pelos professores da rede de educação básica, licenciandos, gestores educacionais, o qual não produz conhecimento de forma sistematizada - como o círculo esotérico -, mas tende a apropriar-se desse, disseminando-o a partir de práticas educativas.

\section{Referências}

Araújo, L. B. (2015). Os três momentos pedagógicos como estruturantes de currículos. Dissertação de Mestrado. Programa de Pós Graduação em Educação em Ciências: química da vida e saúde da Universidade Federal de Santa Maria, Santa Maria.

Auler, D., \& Delizoicov, D. (2006). Educação CTS: Articulação entre Pressupostos do Educador Paulo Freire e Referenciais Ligados ao Movimento CTS. In Seminário Ibérico CTS em la Enseñanza de las Ciencias. Málaga/Espanha.

Auler, D. (2007). Articulação entre pressupostos do educador Paulo Freire e do movimento CTS: novos caminhos para a educação em ciências. Contexto e Educação, 22(77), 167-188. https://doi.org/10.21527/2179-1309.2007.77.167-188

Centa, F. G., \& Muenchen, C. (2016). O despertar para uma cultura de participação no trabalho com um tema gerador. Alexandria: Revista de Educação em Ciência e Tecnologia, 9(1), 263-291. https://doi.org/10.5007/1982-5153.2016v9n1p263 
Centa, F. G. (2015). “Arroio Cadena: cartão postal de Santa Maria?”: possibilidades e desafios em uma reorientação curricular na perspectiva da abordagem temática. Dissertação de Mestrado. Programa de Pós-Graduação em Educação Matemática e Ensino de Física da Universidade Federal de Santa Maria, Santa Maria.

Centa, F. G., Schneider, T., Magoga, T., \& Muenchen, C. (2015). Práticas educativas baseadas na abordagem temática: uma análise dos trabalhos no XIII e XX SNEFs. In XXI Simpósio Nacional de Ensino de Física, Uberlândia, MG/Brasil.

Dalmolin, A. M. T., \& Roso, C. C. (2012). Investigação Temática: Análise de Impactos Pré-Produção de CT Como Encaminhamentos Para a Educação em Ciências. In II Seminário Internacional de Educação em Ciências. Rio Grande, RS/Brasil.

Delizoicov, D. (1983). Ensino de física e a concepção freireana de educação. Revista Brasileira de Ensino de Física, 5(2), 85-98.

Delizoicov, D. (1991). Conhecimento, Tensões e Transições. Tese de Doutorado. Faculdade de Educação da Universidade de São Paulo, São Paulo.

Delizoicov, D., Angotti, J. A., \& Pernambuco, M. M. C. A. (2011). Ensino de ciências: fundamentos e métodos. Cortez.

Fleck, L. (2010). Gênese e desenvolvimento de um fato científico. Fabrefactum.

Freire, P. (1987). Pedagogia do Oprimido. Paz e Terra.

Freire, P. (2011a). Pedagogia da autonomia: saberes necessários à prática educativa. Paz e Terra.

Freire, P. (2011b). A importância do ato de ler: em três artigos que se completam. Cortez. Freire, P. (2011c). Educação como prática da liberdade. Paz e Terra.

Garcia, E. G., Martinelli, M. A., \& Moraes, N. S. (2002). No espelho, as dores e os prazeres das novas caras. In Pontuschka, N. N. (orgs.). Ousadia no diálogo: interdisciplinaridade na escola pública (pp. 189-216). Edições Loyola.

Gehlen, S. T. (2009). A função do Problema no Processo Ensino-Aprendizagem de Ciências: Contribuições de Freire e Vygotsky. Tese de Doutorado. Programa de PósGraduação Educação Científica e Tecnológica da Universidade Federal de Santa Catarina, Florianópolis.

Gehlen, S. T., Strieder, R. B., Caramello, G. W., Feistel, R. A. B., \& Halmenschlager, K. R. (2014). A inserção da abordagem temática em cursos de licenciatura em Física em instituições de ensino superior. Investigações em Ensino de Ciências, 19(1), 155-175.

Giacomini, A., \& Muenchen, C. (2015). Os Três Momentos Pedagógicos Como Organizadores de Um Processo Formativo: Algumas Reflexões. Revista Brasileira de Pesquisa em Educação em Ciências, 15(2), 339-355. 
Giacomini, A., Magoga, T., \& Muenchen, C. (2013). Uma intervenção curricular baseada na abordagem temática: o caso do cultivo do arroz. Enseñanza de las ciencias, 1, $2452-$ 2456.

Guerrero, M. E. (2010). Sonhos e utopias: ler Freire a partir da prática. Liber Livro.

Halmenschlager, K. R. (2011). Abordagem temática no ensino de ciências: algumas possibilidades. Vivências: Revista Eletrônica de Extensão da URI, 7(13), 10-21.

Hunsche, S., \& Delizoicov, D. (2011). A Abordagem Temática na perspectiva da articulação Freire-CTS: um olhar para a Instauração e Disseminação da Proposta. In VIII Encontro Nacional de Pesquisa em Educação em Ciências, Campinas, SP/Brasil.

Lei no 9.394, de 20 de dezembro de 1996 (1996). Lei de Diretrizes e base da Educação Nacional. Brasília: Ministério da Educação.

Lindemann, R. H. (2010). Ensino de química nas escolas do campo como proposta agroecológica: contribuições a partir da perspectiva freireana de educação. Tese de Doutorado. Programa de Pós-Graduação em Educação Científica e Tecnológica da Universidade Federal de Santa Catarina. Florianópolis.

Magoga, T. (2017). Abordagem Temática na Educação em Ciências: um olhar à luz da epistemologia de Fleck. Dissertação de Mestrado. Programa de Pós-Graduação em Educação em Ciências: química da vida e saúde da Universidade Federal de Santa Maria, Santa Maria.

Magoga, T., \& Muenchen, C. (2017). A Abordagem Temática e o Campo das Políticas Públicas: o que pensam os pesquisadores? In XI Encontro Nacional de Pesquisa em Educação em Ciências. Associação Brasileira de Pesquisa em Educação em Ciências. Florianópolis/SC.

Magoga, T., \& Muenchen, C. (2018). A abordagem temática na educação em ciências: caracterização de um estilo de pensamento. Alexandria. 11(2), 131-157. https://doi. org/10.5007/1982-5153.2018v11n2p131

Magoga, T., Schneider, T, Centa, F., \& Muenchen, C. (2015). A escolha dos temas em práticas educativas baseadas na abordagem temática. Vivências: Revista Eletrônica de Extensão da URI, 11(21), 10-22.

Menezes, L. C. (1980). Novo (?) Método (?) Para ensinar (?) Física (?). Revista Brasileira de Ensino de Física, 2(2), 85-97.

Moraes, R. (2003). Uma tempestade de luz: a compreensão possibilitada pela análise textual discursiva. Ciência \& Educação. 9(2). 191-211.

Moraes. R., \& Galiazzi, M. C. (2007). Análise textual discursiva. Ijuí: Editora Unijuí.

Muenchen, C., \& Auler, D. (2007). Abordagem temática: desafios na educação de jovens e adultos. Revista Brasileira de Pesquisa em Educação em Ciências, 7(3), 1-17. 
Muenchen, C. (2006). Configurações curriculares mediante o enfoque CTS: desafios a serem enfrentados na EJA. Dissertação de Mestrado. Programa de Pós-Graduação em Educação da Universidade Federal de Santa Maria, Santa Maria.

Muenchen, C. (2010). A disseminação dos três momentos pedagógicos: um estudo sobre práticas docentes na região de Santa Maria/RS. Tese de Doutorado. Programa de PósGraduação em Educação Científica e Tecnológica da Universidade Federal de Santa Catarina, Florianópolis.

Oliveira, F. A., \& Langhi, R. (2014). Educação em Astronomia: investigando aspectos de conscientização socioambiental sobre a poluição luminosa na perspectiva da abordagem temática. Ciência \& Educação, 20(3), 653-670. http://dx.doi.org/10.1590/151673132014000300009

Pernambuco, M. M. C. A. (1981). Ensino de Ciências a Partir de Problemas da Comunidade. Dissertação de Mestrado. Faculdade de Educação da Universidade de São Paulo, São Paulo.

Pernambuco, M. M. C. A. (2002). Quando a troca se estabelece (a relação dialógica). In Pontuschka, N. N. Ousadia no Diálogo: interdisciplinaridade na escola pública. Editora Loyola.

Pierson, A. H. C. (1997). O cotidiano e a busca do sentido para o ensino de Física. Tese de Doutorado. Faculdade de Educação da Universidade de São Paulo, São Paulo.

São Paulo (1990). Cadernos de Formação 01, 02 e 03. Série Ação Pedagógica na escola pela via da interdisciplinaridade. DOT/SME-SP.

São Paulo (1992). Visões da área. Coleção de autores coletivos. DOT/SME-SP.

Saul, A. M., \& Silva, A. F. G. (2009). O legado de Paulo Freire para as políticas de currículo e para a formação de educadores no Brasil. Revista Brasileira de Estudos Pedagógicos, 90(224), 223-244. http://dx.doi.org/10.24109/2176-6681.rbep.90i224.507

Schneider, T. M., Centa, F. G., \& Magoga, T. (2015). Um olhar para a definição dos temas geradores em práticas educativas de educação em ciências baseadas na abordagem temática. In XVII Fórum de Estudos: Leituras de Paulo Freire. Santa Maria, RS/Brasil.

Schneider, T. M., Centa, F. G., Ilha, G. C., Magoga, T., \& Muenchen, C. (2014). Abordagem temática em sala de aula: uma análise dos trabalhos apresentados no I, VIII e IX ENPECs. In: XV Encontro de Pesquisa em Ensino de Física, Maresias, SP/Brasil.

Silva, A. F. G. (2004). Das falas significativas às práticas contextualizadas: a construção do currículo na perspectiva crítica e popular. Tese de Doutorado, Programa de PósGraduação em Educação da Pontíficia Universidade Católica, São Paulo.

Sousa, P. S., Bastos, A. P. S., Figueiredo, P. S., \& Gehlen, S. T. (2016). Tema Gerador e a Relação Universidade-Escola: Percepções de Professoras de Ciências de uma Escola Pública em Ilhéus-BA. Alexandria: Revista de Educação em Ciência e Tecnologia, 9(1), 3-29. https://doi.org/10.5007/1982-5153.2016v9n1p3 
Strieder, R. B., Caramello, G. W., \& Gehlen, S. T. (2010). Abordagem de temas no ensino médio: compreensões de professores de física. In XII Encontro de Pesquisa em Ensino de Física, Águas de Lindóia, SP/Brasil.

Torres, J. R. (2010). Educação Ambiental Crítico-Transformadora e a Abordagem Temática Freireana. Tese de Doutorado. Programa de Pós-Graduação em Educação Científica e Tecnológica da Universidade Federal de Santa Catarina, Florianópolis.

Zanella, L. C. H. (2009). Metodologia de estudo e de pesquisa em administração. Florianópolis: Departamento de Ciências da Administração/UFSC; CAPES:UAB..

\section{Thiago Flores Magoga}

https://orcid.org/0000-0002-1532-1355 Universidade Federal de Santa Maria Pós-Graduação em Educação em Ciências Santa Maria, Rio Grande do Sul, Brasil thiago.ufsm@gmail.com

Cristiane Muenchen

${ }^{0}$ https://orcid.org/0000-0003-3144-0933 Universidade Federal de Santa Maria

Departamento de Física Centro de Ciências Naturais e Exatas da UFSM Santa Maria, Rio Grande do Sul, Brasil crismuenchen@yahoo.com.br 